\title{
Countrywide Manors
}

\section{Case Question}

Write a draft report on staff motivation with reference to job design and productivity issues.

\section{Suggested Answer}

(a) Introduction to general theories of motivation, e.g.:

(i) Herzberg - hygiene factors and motivator factors

(ii) Maslow - hierarchy of needs

(iii) McGregor - theory $\mathrm{X}$ and theory $\mathrm{Y}$

(iv) Vroom - expectancy theory

(b) How the theories can be applied to the situation in the advance reservations department.

(c) The role of management in motivating staff.

(d) Methods of improving motivation to include job design (job enrichment, job enlargement, job rotation), pay and incentive schemes and participation.

(e) A system for monitoring individual productivity levels.

(f) Techniques used to measure motivation, e.g., attitude surveys, analysis of labour turnover rates and records of absenteeism. 